\title{
Armed Forces as an Element of National Power, and Compulsory Military Service
}

\author{
Suat Begeç, Turkey
}

\begin{abstract}
Whether military service should be done as a national duty or left to the professionals has been discussed for a long time both in Turkey and across the world. In order to answer this question and make relevant suggestions, this paper begins with the recruitment system in the Turkish Armed Forces during the history. Subsequently, armed forces of neighbor countries, their communication strategies and of those politically linked with Turkey as well as the world armies carrying weight for the scope of this study are all analyzed. Thirdly, current military service and its flawed aspects are explained. Finally come suggestions on how the military service should be.
\end{abstract}

Keywords: Armed forces, compulsory military service, national army, recruitment 


\section{Introduction}

Neither numbers nor technology wins in a war... The winner is always the heart. There is no might that can stand against a unit banded together. Soldiers believe that if they lose their life in a war, they will die a martyr and be worthy of heaven; and that if they survive they will be a veteran and leave unforgettable memories to his children. This belief renders them fearless. This bestows on their commanders a power that few leaders have.

Power is the ability to influence people and events. Power is the ability that leaders and managers gain and enjoy through their personalities, activities and situations within the organizational structure [Newstrom \& Davis, 2002:272]. Organizational structure consists of certain sources such as statutory authority, rules and practices, decision-making techniques, control measures, information and technology, alliance, management cadres, and groups [Mullins, 1999:782]. All these sources constitute national power. Because power not only important for the leaders but also for the nations. National power is a combination of political, economic, demographic, geographical, historical and military strengths. National power is important for security and defence of the country. Military strength is organized to show or use force in carrying out the national policy and obtaining/or protecting national objectives. It is an entity consisting of people who are unified for certain common purposes; who complement the activities of each other; who are equipped with necessary weapons, tools and materials; and who implement certain technology individually or in groups [Öztorun, 2009:182]. It is shaped according to the threat, national interests and power; and supported by rules and regulations.

In a society, laws, rules and regulations are largely defined in accordance with history, culture, and customs. These are generally accepted rules emerged as a result of the characteristic of a society and the nature of people. In history, Turks founded many different states with different names within the region extending from Asia to Europe; and they ruled on three continents by composing the strongest armies in the world. They are often referred to as being an army-nation by many countries due to this feature peculiar to them. [Ögel, 1991: VII]. 


\section{Historical Process}

Turkish Land Forces is presumed to be founded organizationally first by Mete Khan in 209 B.C. during the Asian Hun Empire. Under the Hun rule and other Central Asian Turkish States, every Turk was considered as a warrior. Therefore, regular armies were not founded at those times. It is under the rule of Mete Khan that for the first time the decimal organizational system was established; the empire was divided into fourteen command regions and an army consisting of twelve thousand cavalrymen was formed [Manual, 1996:1].

Oghuz Turkish State that subsequently emerged on the scene of history assigned this military organization to the Seljuk State, and later to the Ottomans. The Ottoman Empire possessed the military organizational structure and its forces were composed of regular, salaried and landowning soldiers. The foundations of current Land Forces go back to the Ottoman Army. The Ottoman Army, the first model of regular armies in history, was founded in 1363 by the third Ottoman Sultan, Murad I. With the ratification and implementation of Penchik Law (1363) a regular, standing and paid army was founded under the name of Kapıkulu organization [Manual, 1996:5-15]. This newly founded army was all along ready in the barracks even in peacetime; and the personnel adopted the military service as a profession; did nothing other than military service; and wore an official uniform [Manual, 1969:1]. In 1845 , twenty seven officers were promoted to the rank of staff officer in order to well educate the future commanders of this army. Thus, staff officer organization was established for the first time in the Ottoman Army [Manual, 1966:3]. As from the 19th century, there were four different paid recruitment systems in the Ottoman Army: fief-holders, paid raiders, salaried kapikulu, and unpaid raiders [Manual, 1996:5-15]. Before the establishment of these systems, there were armies mobilized only during wartime and dissolved at the end of the campaign.

Meanwhile, Renaissance and Reform movements broke out in the West and Industrial Revolution took place. In 1774 the USA was founded on the new continent, while the old continent witnessed important changes such as the 1789 French Revolution and the 1917 Bolshevik Revolution. These developments also affected the Ottoman Empire. Within the time elapsed, catching up with the military and technologic level of the major powers of the time was targeted by the foundation of Nizam-1 Cedid by Selim III; the novelties brought in by Mahmoud II; the 1839 Tanzimat Firman; the proclamation of the first constitutional monarchy in 1876 and the second one in 1908. However, all these efforts could not prevent the demise of the Ottoman Empire. 
Empires are like mothers. They give a birth to their children at the expense of their lives. The Ottoman Empire gave a birth to the Republic of Turkey while it was dying. The Republic of Turkey has charged Turkish Armed Forces (TAF), one of her foundation stones, with various tasks since the War of Independence. In order to fulfill these tasks, TAF served and still continue to serve in Korea, Somali, Bosnia, Kosovo and Afghanistan under the auspices of NATO and the UN.

\section{A Look on World Armies}

In this paper, Armed Forces of neighbor countries and of those politically linked with Turkey as well as the world armies carrying weight for the scope of this study will be analyzed. Information used in this paper has largely been compiled from the official websites of the armed forces of the countries in question. Comparative strengths of the World Armed Forces are shown in the Table.

Bulgarian Armed Forces (BAF) [Bulgarian Army, 2010]: Ministry of Defense is in charge of political leadership of the BAF while military command remains in the hands of the General Staff. There are three main branches within the BAF: Land Forces, Navy, and Air Force. The Land Forces are functionally divided into Deployable and Reserve Forces. Their main functions include deterrence, defense, peace support and crisis management, rescue and humanitarian missions. The basic missions of the BAF are support for the international peace and security, participation in search-and-rescue operations, support and protection of the population at times of natural disasters.

The Joint Operational Command is a formation of the BAF directly subordinated to the Chief of Defense. It is a structure tasked to plan and conduct operations within the territory of the country and abroad, and to carry out command and management on operational level in its capacity as a body responsible for the application of interoperability principle. It controls the readiness of the $\mathrm{BAF}$ and plans, organizes and coordinates the logistic provision and communication-information support of the additional formations of the BAF. Bulgaria ended conscription in 2008 . The age for voluntary service is $18-27$ years and duration of the service obligation is 6-9 months [Bulgarian Military, 2010].

Armenian Armed Forces [The military doctrine of Armenia, 2010]: The main functions of the Armed Forces are: to ensure the necessary combat capabilities for military objectives; to 
protect the fundamental values of national security; to prevent the possible armed aggression; and to neutralize tension areas. They prevent and neutralize subversive intelligence and terrorist activities; ensure informational security and realize activities aiming at neutralization of disinformation propaganda. Armenian Armed Forces have structures similar to those of their counterparts in the former Soviet Union, except that the highest organizational level is a smaller unit, the brigade, rather than the traditional division. Armenian military analysts maintain that although the Armed Forces of Armenia and Nagorno-Karabakh are smaller than the Azeri Armed Forces, they are more combat-capable, mobile and have combat experience. The weakness of Nagorno-Karabakh Armed Forces is their lack of any army aviation - a constraint factor in active military operations [Armenian Army, 2011].

The Armenian Air and Air Defense Forces are tasked with defending the country's territory from air incursion, providing defensive air cover and close air support to the ground forces, tactical transport within the battle space and maintaining trained and ready formations. In stark contrast to its ground forces, Air Force squandered even a nominal offensive and defensive capability. The focus has been on providing both tactical and national air defenses that are credible and sufficient to combat the likely threat. The country's national strategic air defenses are significantly upgraded by the stationing of Russian air defense units, the joint air defense command post and joint surveillance network [Armenian Air Force, 2011]. The age of compulsory military service is $18-27$ years, and of voluntary service 18 years. Duration for compulsory service is 24 months, while it is 15 years for army reserves.

Georgian Armed Forces (GAF) [Major missions and functions of the GAF, 2011]: Missions of the GAF are defined by the Law on Defense and include such objectives as protection of independence and territorial integrity and fulfillment of international commitments. GAF performs these functions under the direction and authority of the MoD. In order to fulfill the national interests of Georgia, the GAF is assigned to maintain forces in a high state of readiness; to carry out political decisions made by the executive and legislative branches of the Georgian government; to identify threats based on the current military-political situation; to develop the force structure of the GAF; and to accomplish military cooperation in accordance with international treaties and agreements.

GAF includes three deputy chiefs of staff subordinated to the Chief of Joint Staff. Land Forces work under one of these deputy chiefs of joint staff. The same Deputy Chief embraces 
departments of personnel, intelligence, operational, strategic and resources planning, logistics, communications and combat preparation as well as military representation and topographic offices and armament control and verification division. There are also administrative department of Joint Staff, Logistic Support Command, Special Operational Forces, Military Police, National Guard, and Trainings and Military Education Command. National Guard Department represents the base of the foundation for modern GAF. Conscription based military service period in Georgia is 18 months.

Iraqi Security Forces (ISF) [The report of the Independent Commission on the ISF, 2007]: ISF are composed of MoD and Ministry of Interior (MoI) Forces. Iraqi Army and Special Forces, Air Force, and Navy report to the MoD. Under the MoI are the National Police, the Iraqi Police Service, the Department of Border Enforcement, the Facilities Protection Service, and the Coast Guard. In 2004, the Coalition established the Multi-National Security Transition Command-Iraq to focus exclusively on helping to establish and develop the ISF so that the Government of Iraq would be able to provide for its own security. The command is responsible for working with the Government of Iraq to generate and train ISF, and to develop administrative capacity within the MoD and interior to support the ISF.

The MoD comprises a Joint Headquarters, the Iraqi Land Forces Command, the Iraqi Special Operation Forces, and the Iraqi Army, Navy, and Air Force. The ministry's core mission and functions are organizing, training, equipping, sustaining, and employing the Iraqi Joint Forces in accordance with the Iraqi Constitution, government direction, and the law. Coalition assistance to the MoD is provided largely through the Coalition Military Assistance Training Team (CMATT) and the two national-level transition teams assigned to the MoD. CMATT advises both to the MoD and the Joint Headquarters on manning, training, equipping, basing, and sustainment for ISF units throughout Iraq as they work toward operational readiness. The MoD Transition Team advises civilian leadership at the MoD.

Iranian Armed Forces [Iranian Military, 2010]: Iran's military structure is broken up into three branches: Islamic Republic of Iran Army (Artesh), Islamic Revolutionary Guard Corps (IRGC), and the Basij Resistance Force. The Artesh is Iran's conventional military force. It is comprised of the Army, Navy, and Air Force, which are responsible for defending Iran's territory and maintaining internal order. The IRGC was established in 1979 in conjunction with the Islamic Revolution. Originally, the IRGC was responsible for enforcing the new 
government's Islamic codes and morality. However, its responsibilities have evolved to protect the regime as a whole, including national security, protecting the borders, homeland security, and law enforcement. The IRGC is about one third of the Artesh. It boasts air and naval forces as well. The Basij took on an homeland security role of quelling domestic dissent against the regime and maintaining security in large urban centers during the 1990s. Although the regime's official policy attempts to divide labor between the Artesh, the IRGC, and the Basij, this policy in practice is rarely followed. The IRGC remains the dominant player in Iran's military apparatus. The Basij are rarely seen as one of Iran's military pillars. Even the IRGC no longer view them as important, because they don't have the IRGC's level of capability and professionalism.

Syrian Armed Forces [Cordesman, 2003]: Syrian Army is organized into 3 Corps with a total of seven Armored Divisions, three Mechanized Divisions, one Republican Guard Division, and three Special Forces Brigades. Additionally, it has four Infantry Brigades, one Border Guard Brigade, and two Artillery Brigades. There is a Tank Regiment, and ten Special Forces Regiments. The Syrian Air Force's attack capability includes a total of 10-11 squadrons and its Air Defense Forces capability includes a total of sixteen squadrons. Air Defense Command is one of the largest elements of its military forces, and it has two Air Defense Divisions, twenty five Air Defense Brigades, and a total of some one hundred and fifty Surface-to-Air Missile Batteries. Syrian Navy has two semi-operational Petya-III class guided Missile Frigates, eighteen Patrol Crafts, five Mine Warfare Craft, and three medium class Amphibious Ships. Syria has little or no capability, however, for amphibious landings and warfare. The mandatory draft period is 18 months for males from the age of 18 .

Hellenic Armed Forces (HAF) [HAF, 2011]: In peacetime, the HAF have the objectives to: be on continuous alert for the security of the national territory; maintain high operational readiness for the prevention and effective confrontation of threats as well as ensuring rapid response capability; contribute to international security and peace; contribute to activities of social aid and support state services for the confrontation of emergency situations. Defense policies of the HAF are defined separately for each branch. In land, the HAF strives to develop a flexible, rapid and effective force as well as an appropriate organization and structure, to be able to ensure the territorial integrity of the landlocked and insular country and to contribute to the defense of Greek Cypriot Administration. At sea, it aims to develop a naval power that will be able to protect the her sovereign rights; to defend the Greek coasts 
and islands; to keep the sea lines of transportations open; to show power in land and to display a naval presence at all the Greek territorial waters as well as other sea areas and the East Mediterranean. In the air, its tasks are: to protect the rights for sovereignty; to ensure the air defense of the country; to support the Armed Forces; and to assure the operational capability in the widest area of East Mediterranean.

The main formations of the army are brigade, division, corps and field army. The structure of the forces of the Army includes the General Staff of Army, the Headquarters of the 1st Army, a number of headquarters of the army corps, a number of divisions and brigades, as well as a number of schools and training centers. The navy incorporates a powerful fleet. The structure of the Naval Forces includes the General Staff of the Navy, the Command Post of the Fleet, the Naval Training Command, the Logistics Command of the Navy and a number of naval commands and services. The Air Force incorporates an air fleet (transportation, combative, and training), the congruent structure, as well as an air control, which cooperates with an antiaircraft defense. The structure of the Air Force includes the General Staff of Air Force, the Command Post of Regular Army, the Air Support Command, the Air Training Command and a number of units and services. All male Greek citizens must join the army during January and February of the year running their 19th year of age for 12 months.

Russian Armed Forces (RAF) [RAF, 2011]: The RAF consists of three major forces Land Forces, Air Force and Navy. Land Forces capabilities allow for large-scale offensive operations to defeat the enemy, occupy its key terrains, deliver strikes to enemy depth, repel its attack and, finally, confirm the rout in cooperation with other components of the RAF. Land Forces constantly maintains its combat abilities through training, international peacekeeping, joint international missions for the purpose of being ready to react on short notice in case of a threat of warfare and defend the nation. Navy is designated for naval defense, naval and amphibious warfare at maritime threaters, protection of the maritime rights and interests of the country, protection of shipping lines, delivering conventional or nuclear strikes in support of the Land Forces engaged in territorial combat operations. The strategic task of the Navy includes nuclear deterrence by use of submarine-borne nuclear missiles. Air Force is responsible for providing air reconnaissance, gaining air superiority. Air Force is in charge of aerial defense of national industry hubs and troops, timely air warning, delivering strikes at enemy targets, supporting Land Forces and Navy, airborne operations, air deployment. 
The Strategic Rocket Forces (SRF) is a division of the RAF that controls Russia's land-based Intercontinental Ballistic Missiles and the state's main tool of ensuring strategic deterrence alongside with strategic components of Air Force and the Navy. The SRF is capable of delivering mass and single nuclear strikes at enemy's defense or industry hubs by one or a few strategic aerospace approaches simultaneously. Space Forces is the recently formed (June, 2001) branch of the RAF, which is responsible for space defense. Airborne troops are air-mobile or parachute-dropped units within RAF that can be transported by aircraft and dropped behind enemy lines to fight almost anywhere with minimum prior notice. They directly report to their Commander and are divided into airborne divisions, brigades, and minor units. Compulsory military service in Russia lasts 12 months. Those who complete compulsory service are included in the reserves up to the age 50.

The US Armed Forces: The US Army's mission is to fight and win nation's wars by providing prompt, sustained land dominance across the full range of military operations and spectrum of conflict in support of combatant commanders. The Army, as one of the third military departments (Army, Navy, and Air Force) reporting to the DoD, is composed of two distinct and equally important components: the active and reserve components. The reserve components are the US Army Reserve and the Army National Guard (ARNG) [US Army Organization, 2010]. Members of the active components work on full-time basis, for a period of 2-6 years.

US Army Reserve Command (USARC) mission is to provide trained and ready units and individuals to mobilize and deploy in support of the national military strategy. The USARC enables the Army to do more with fewer resources, by providing a flexible, well-trained, complementary force to meet the specific needs and challenges of each new mission. It trains soldiers at the highest possible level in one of nearly two hundred specific skills in order to support the Army on air, land or sea missions. A four year college degree is mandatory for all commissioned officers above the rank of lieutenant, and many officers have graduate degrees. Qualified individuals between the ages of 17-40 can join the reserves and serve until their mandatory removal date [USARC, 2011]. The ARNG is composed primarily of civilians who serve their country, state and community on a part time basis. The ARNG has a unique dual mission that consists of both federal and state roles. For state missions, the governor, through the state adjutant general, commands the Guard Forces. In addition, the President of the US can activate the ARNG for participation in federal missions. There are fifty-four ARNG 
organized in all fifty states, three territories and the District of Columbia. Most people between the ages of 17-35 are eligible to join the ARNG for 20 years or more [US ARNG, 2011].

The US Armed Forces train all of its components at high-level institutions. Renowned as the world's leading leader trainning and development institution, West Point accomplishes its mission by developing cadets intellectually, physically, militarily, ethically, spiritually, and socially [West Point, 2010]. Since 1882, Combined Arms Center and its predecessor organizations have been engaged in the primary mission of preparing the Army and its leaders for war in Fort-Leavenworth [Combined Arms Center, 2010]; and the Army trains its senior officers at US Army Training and Doctrine Command [TRADOC, 2010]. In order to provide the world's best infantry soldiers and trained units, and to provide a power projection platform that can deploy soldiers and units anywhere in the world on short notice, the Fort-Benning known as the "Home of the Infantry" was established in 1918 [Fort-Benning, 2010].

The USA is probably one of the best implementer of the professional military system in the world. Still, Lt. Gen. Douglas Lute, assistant to the President and Deputy National Security Adviser for Iraq and Afghanistan, stated that "it makes sense to certainly consider return to a mandatory draft", in an interview by National Public Radio [Silva, 2007]. Likewise, US Congressman Charles Rangel introduced a bill in both 2003 and 2006 which if passed will "provide for the common defense by requiring all persons in the US, including women, between the ages of 18-42 to perform a period of military service or a period of civilian service in furtherance of the national defense and homeland security" [Staff, 2006].

German Armed Forces [German Armed Forces, 2011]: The political and constitutional raison d'étre of the German Armed Forces (Bundeswehr) is to defend Germany against external threats; to counter international terrorism and to prevent conflicts; to manage crises; support allies; protect Germany and its population; to participate in rescue and evacuation operations; and to provide support in cases of disasters and accidents.

The Federal MoD is characterized by its dual responsibility. It performs the functions of a civilian ministry and acts as the Armed Forces command authority. The federal MoD is the Commander-in-Chief of the Bundeswehr in peacetime and the supreme superior of all military personnel. In addition, the minister is the head of the Federal Defense Administration (FDA) and thus the superior of all civilian employees of the Bundeswehr and the ministry. 
Should a state of defense be declared, the command authority of the armed forces passes to the Federal Chancellor. The military organization of the MoD is structured in five service staffs: Armed Forces, Army, Air Force, Navy, and the Bundeswehr Medical Service.

The Chief of Staff is the highest-ranking service member of the Bundeswehr and the military adviser of the Federal MoD. He is responsible to the minister for the development and implementation of an overall military defense concept. The Armed Forces Staff develops the overall planning of military defense; conceives the basic principles of military policy; controls the Bundeswehr's operational planning and mission conduct; and works out basic guidelines for leading, educating and training soldiers. The Armed Forces Staff is structured into seven departments: Personnel and Training Matters; Military Intelligence; Military Policy and Arms Control; Logistics, NBC Defense and Protection; Operations; Planning; and Organization, Stationing of Forces, Infrastructure, Territorial Tasks and Command Support [Keymer, 2010:280-281]. The period of compulsory military service has been reduced to 6 months as of 2010. Military service could be prolonged up to 23 months. Commissioned and noncommissioned officers serve until the age of 60 , and the privates until 45 in the reserves.

British Army [British Army, 2010]: The British Army consists of the General Staff, the deployable Field Army (FdA) and the Regional Forces that support them, as well as joint elements that work with the Royal Navy and Royal Air Force. Its primary task is to defend the interests of the UK. The command structure is hierarchical with divisions and brigades responsible for administering groupings of smaller units. Major Units are regiment or battalion-sized with minor units being smaller, either company sized sub-units or platoons.

All units within the service are either Regular (full-time) or Territorial Army (part-time), or a combination with sub-units of each type. The Commander-in-Chief Land Forces reports directly to the Chief of the General Staff to deliver forces that are properly trained and equipped to sustain current operations. This is achieved through four subordinate commands: FdA, Personnel and Support Command, Force Development and Training Command, and Joint Helicopter Command.

The Army Recruiting and Training Directorate is responsible for each stage of a potential recruit's progress from the recruiting office, through a Recruit Selection Center, into recruit training, through specialist courses before they are finally posted to their regiment in the FdA. Potential recruits are normally aged between 16 and 33 years. As a trained soldier the 
minimum length of service will be four years and three months from the age of 18 , or from the start of training, if over 18 [Soldier selection, 2010].

Chinese Armed Forces (CAF) [Structure and organization of the CAF, 2010]: The Armed Forces of the People's Republic of Chinese (PRC) are composed of the People's Liberation Army (PLA), the active and reserve components, the Chinese People's Armed Police Force and the militia. The Central Military Commission (CMC) of the PRC directs and assumes unified command of the CAF. The National MoD under the State Council directs and administers national defense work. The active components of the PLA are the country's standing army, which mainly undertake the task of defensive military operations, and help to maintain social order, if necessary, in accordance with the law. Its basic organizational structures can be categorized into the general headquarters/departments, the services and arms and the military area commands.

The PLA's general headquarters/departments system is composed of the General Staff Headquarters, Political, Logistics and Armaments Departments, which are placed under the leadership of the $\mathrm{CMC}$. The $\mathrm{CMC}$, through these four general headquarters/departments, directs and commands all the military area commands and the services and arms. The General Staff Headquarters is the leading organ of all military work of the CAF. It organizes and leads the military construction of the CAF, and organizes and commands their military operations.

The PLA is composed of three services -Army, Navy and Air Force- and an independent Second Artillery Force. The military area commands of the PLA are military organizations set up according to the state's administrative divisions, geographical locations, strategic and operational orientations, and operational tasks. Under each military area command are Army Combined Corps, units of various arms, logistical support units, and provincial or garrison commands. Their major functions include organizing and coordinating joint operations and exercises of the ground, naval and air forces in each military area; exercising direct leadership over Party affairs, military training, administration, political work, logistical and armaments support of the Army units under its jurisdiction; and directing the militia, military service, mobilization, civil air defense and battlefield construction work in the military area. The militia is a component of the state's armed forces. The conscription period in PRC is 2 years.

Israel Defense Forces (IDF) [IDF, 2010]: IDF ranks among the most battle-trained Armed Forces in the region. The IDF's security objectives are to defend the sovereignty and 
territorial integrity of the State of Israel; to deter all enemies and to curb all forms of terrorism which threaten daily life. The IDF's three service branches (ground forces, air force and navy) function under a unified command. The ground corps consists of paratroop/infantry, armor, artillery, and engineers; and is responsible for training, equipment and development of these branches. Northern Command faces Syria and Lebanon; Central Command faces Jordan; and Southern Command faces Egypt.

In order to achieve military and strategic goals, these commands are responsible for the preparation of forces and sectors, and for ensuring the security in peacetime and in times of emergency. Their subordinate units consist of brigades and divisions. They operate independently. All eligible men and women are drafted at age 18. Men serve for 3 years, women for 24 months. Upon completion of compulsory service, each soldier is assigned to a reserve unit up to age of 51 [Organizational structure, 2010].

\section{Military Service in Turkey}

According to the Recruitment Directive, every Turkish male citizen must be drafted between the ages of 20-41. And in accordance with the TAF Medical Eligibility Regulation, every Turkish man without any medical defect or disease impeding military service must be conscripted [MSY: 70-1C, 2000:1-3]. Thus, it is clear that being a healthy Turkish citizen is sufficient for military service. But the obvious infringement is the short-term military service through payment in amounts stated in law. Another practice is the assigning soldiers as teachers within the Ministry of National Education. One other infringement is assigning, in drafting period, the exceeding amount of the soldiers in the training centers in the demanding public institutions upon the completion of their basic military service. Existence of such various practices damages the simplicity principle of the military profession. Although these practices are carried out within the framework of bona fides and necessities, they make deep wounds in public conscience.

Graduates of four or more year-faculties, academy, university and institute; graduates of foreign higher education institutions that are approved as equivalent by relevant authorities are recruited as reserve officers in case they have no medical handicap for military service [MSY: 70-1C, 2000:8-9]. The amount of reserve officer candidates demanded by TGS serves for 15 months, the rest for 6 months as short-term privates [Ibid, 8-50]. The majority of the short-term conscription consists of basic military training, leaves and period of adaptation to 
the main detachment. The remaining period is shorter; thus short-term privates can not be employed in homeland security operations. This leads to discrepancy among soldiers and damages the main goals. On the other hand, the reserve officers and short-term privates bring a different perspective to Turkish Army and strengthen it more.

Recruitment is carried out on a quarterly basis. The first three month period is the basic training phase and executed in the boot camps. The remaining period is the special training phase and completed in the base units. Conscripts stay far away from their ordinary lives for fifteen months. This period is very long in today's conditions. However, it may be rendered effective and fruitful with a few arrangements. Difference between the service duration for the conscripts should be removed and military service should be limited to twelve months for everyone. Those who have less than a four year university education may serve as privates without any interval, while university students may serve during their educational process. Normally, university education starts at the ages of 19-20 and the normal drafting age is 20 . The twelve month conscription duration equals to four three month semesters. The undergraduate education lasts four years, and summer holidays three months. These periods equal to the conscription terms. Those who reach their 20th birthday and continue their university education may be drafted during their summer holidays in four terms. In the first three month summer holiday, they may receive basic training; in the second three month they may get squad and platoon training; in their third class they may be trained on company and battalions; and in the last term they may be exposed to a special training phase. In order to preclude bad faith, only a three month service for each year and graduation at the end of four years should be compulsory.

\section{Leaderaship and Military Discipline}

The commanding officers within Compulsory Army are like intercity bus drivers. Bus drivers take a group of passengers, who come together without their personal initiative, to where they want to arrive. They let the passengers down, and let them get in all along the road. The driver has not selected any one of the passengers but himself. He tries to transport a group of coincidentally gathered people to their common destination. Similarly, the commanding officers can choose neither their appointment location nor the personnel they will work with. All are determined by the major command. What the commanding officer can do is to command and control his unit according to the nature of the duty. 
During the Korean War, a "death march" was started towards Red China together with Turkish soldiers, the majority of whom were taken prisoners by the communists during Kunuri battles in a horse de combat situation [Kıran, 1965:179]. In December North Korea is snowy, cold and hard to survive. There were the wounded and the sick within the convoys. The road was long; conditions were severe. Any captive who couldn't stand this lengthy, difficult march and fell down were warned by guards to stand up. Ones who could stand up and walk saved their lives. But the situation was different for Turkish prisoners. Before guards took action, Turkish prisoners in good-condition helped their exhausted compatriots; gave hand to them; and even carried them on their backs by turns [Artuç, 1990:356]. The mystery of few Turkish casualties during this lengthy and difficult death march up to the northern Yalu River-China is the Turkish soldiers' understanding of military discipline.

At the Prisioners of War (PW) camp, the communists first had the captives take off all the uniforms given by the UN or respective countries of each soldier; and issued instead uniforms without any rank symbols on. The command chain never changed among Turkish soldiers all through the captivity. When the guards imprisoned the highest-ranking Turkish soldier in the camp (captain), the second highest-ranking Turkish prisoner (lieutenant) took on the command and continued the order. The foundations of this conduct lie firstly in the traditional Turkish familial discipline, and then in the military discipline in the barracks. Military life and civilian life differ in every country. In many countries discipline starts with wearing a uniform, while Turks get it from the mothers and implement within the family [Sayılan, 1996: 465-466]. That's why although 5-10 prisoners died daily in the PW camps; Turks did not suffer casualties due to their solidarity, discipline [Rusçuklu, 2005:246], and leadership of their officers.

\section{Conclusion}

As it is seen, every country has set different missions, tasks, duties, duration, and budget for its Armed Forces. These differences stem from the characteristics and security needs of each country, dimension of the threats, other elements of national power, and interests. The motives of one country may be negligible for another. Security concerns of Turkey are different from other countries'. Turkey has borders with eight countries: Armenia, Bulgaria, Georgia, Greece, Iran, Iraq, Syria, and Nakhchivan Autonomous Republic (Azerbaijan). Its neighboring countries have different political structures, languages, religions and cultures. 
Turkey has been fighting against separatist terrorism since 1984. Hence, it has to organize its security system differently from other countries and has to develop a national system.

Compulsory military service that is claimed to be difficult to implement or has lost its validity has an intimate and strong influence. Should leaders are organized adequately; there will be no need for professional army. TAF has always been conceived as not only a compulsory national duty but also a training center. Compulsory military service practice still continues in an updated manner. Those with four year university degrees or higher should be drafted as lieutenant, and other conscripts as private.

National army system has overcome defence and security of the country. Because national problems can be solved through national powers. 
TABLE: COMPARATIVE TABLE OF THE ARMED FORCES (Hacklett, 2010)

\begin{tabular}{|c|c|c|c|c|c|c|}
\hline \multirow[b]{2}{*}{ COUNTRY } & \multicolumn{4}{|c|}{ ARMED FORCES } & \multirow[b]{2}{*}{ 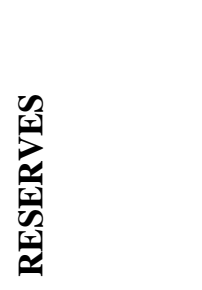 } & \multirow[b]{2}{*}{ 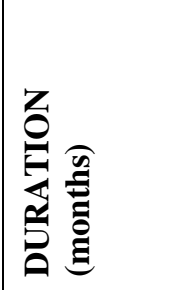 } \\
\hline & $\underset{\Xi}{Z}$ & $\frac{1}{z}$ & 旁 & | & & \\
\hline TURKEY & 402.000 & 48.600 & 60.000 & 102.200 & Up to age 41 & 15 \\
\hline BULGARIA & 16.268 & 3.471 & 6.706 & 34.000 & 302.500 & $6-9$ \\
\hline ARMENIA & 43.772 & - & $\begin{array}{l}\text { Air } 1.044 \\
\text { ADA:1.868 }\end{array}$ & 4.748 & $\begin{array}{l}210.000 \\
15 \text { years }\end{array}$ & 24 \\
\hline GEORGIA & 17.767 & 495 & 1.310 & 11.700 & & 18 \\
\hline IRAQ & 186.957 & 2.000 & 3.000 & $386.312 \mathrm{MoI}$ & & \\
\hline IRAN & $\begin{array}{l}350.000 \\
\text { IRGC } 125.000\end{array}$ & 18.000 & 30.000 & 40.000 & 350.000 & \\
\hline SYRIA & 220.000 & 5.000 & $\begin{array}{l}\text { Air } 40.000 \\
\text { ADA: } 60.000\end{array}$ & 108.000 & 314.000 & 30 \\
\hline GREECE & 93.500 & 20.000 & 31.500 & \begin{tabular}{|l} 
Joint 11.600 \\
4.000
\end{tabular} & 237.500 & 12 \\
\hline RUSSIA & $\begin{array}{l}360.000 \\
\text { Airborne } 35.000\end{array}$ & 142.000 & 160.000 & $\begin{array}{l}449.000 \\
\text { Other } 330.000\end{array}$ & $\begin{array}{l}20.000 .000 \\
\text { Up to age } 50\end{array}$ & 12 \\
\hline USA & 662.232 & 335.822 & 334.342 & \begin{tabular}{|l|}
11.035 \\
3.376 \\
Coast Guard 7.659 \\
\end{tabular} & 864.547 & Professional \\
\hline GERMANY & 163.962 & 24.407 & 62.244 & & $\begin{array}{l}\text { COs-NCOs: } \\
60 \\
\text { Private } 45 \\
\end{array}$ & $\begin{array}{l}9 \\
10-23 \text { for } \\
\text { volunteers }\end{array}$ \\
\hline ENGLAND & 100.290 & 35.650 & 39.750 & & 199.280 & Professional \\
\hline PRC & 1.600 .000 & 255.000 & $\begin{array}{l}300.000- \\
330.000\end{array}$ & $\begin{array}{l}660.000 \\
\text { Missile } 100.000\end{array}$ & 510.000 & 2 years \\
\hline ISRAEL & 133.000 & 9.500 & 34.000 & 8.050 & 565.000 & \begin{tabular}{|l|} 
COs 48 \\
Others 36 \\
Women 21
\end{tabular} \\
\hline
\end{tabular}




\section{Acknowledgment}

Special thanks to Burcu KABAKCI and Arzu ERKAAN, Translator \& Interpreter at TGS, and the anonymous reviewers whose comments, suggestions, assistances and translations helped to improve and clarify this manuscript. 


\section{References}

Armenian Air Force, http://www.globalsecurity.org/military/world/armenia/af.htm, retrieved on 24.01.2011.

Armenian Army, http://www.globalsecurity.org/military/world/armenia/army.htm, retrieved on 24.01.2011.

Artuç, İ. (October 1990). Kore Savaşlarında Mehmetçik. Istanbul: Kastaş Co. Publications.

British Army, http://www.army.mod.uk/structure.aspx, retrieved on 24.11.2010.

Bulgarian Army, http://www.md.goverment.bg/en/ba_sv_history.html, retrieved on 24.11.2010.

Bulgarian Military, https://www.cia.gov/library/publications/the-worldfactbook/geos/bu.html, retrieved on 24.11. 2010.

Combined Arms Center - Fort Leavenworth, http://usacac.army.mil/cac2/overview.asp, retrieved on 22.10.2010.

Cordesman, Anthony H. If it's Syria: Syrian Military Forces and Capabilities. Center for Strategic and International Strategy - CSIS, 15 April 2003, 1800 K Street N.W., Washington DC 20006, retrieved on 06.12.2010.

Fort Benning, https://www.benning.army.mil/infantry/leaders/, retrieved on 22.10.2010.

German Armed Forces/Bundeswehr, http://www.bmvg.de, retrieved on 17.01.2011.

Hacklett, J. E. (2010). The Military Balance 2010, The annual assessment of global military capabilities and defense economics. UK: Taylor and Francis, 4 Park Square Milton Park Abington, Oxon OX14 4RN.

Hellenic Armed Forces, http://www.mod.mil.gr/en/armed-forces.html, retrieved on 04.01.2011.

Iranian Military, http://hormuz.robertstrausscenter.org/iran_military, retrieved on 26.11.2010. Israel Defense Forces, http://www.mfa.gov.il/MFA/Facts+About+Israel/State/THE+STATE+Israel+Defense+Forces+-IDF-htm, retrieved on 06.12.2010.

Keymer, Eleanor; German Army,

http://www2.janes.com/docs/sample/pdf/jwarsample.pdf, Jane's War, Issue 27; June 2010, pp.280-281.

Kıran, M. (1965). Şafakta Hücum “Kore Harbi”. A. D. Tugayları, Ankara: TGS Printing House.

Major missions and functions of the Georgian Armed Forces, 
http://www.mod.gov.ge/index.php?page=-10\&Id=54\&lang=1, retrieved on 03.11.2010.

Manual. (1966). Türk Genelkurmay Başkanlığının Özet Tarihçesi, Turkish General Staff, Directorate of Military History. Ankara.

Manual. (1969). "Kara Kuvvetlerinin tarihçesi 1363-1968; Tarihte ilk daimi ordunun kurulması". Istanbul, Y1ldız: Army War Colleges Printing House.

Manual. (1996). Kuruluşundan Milli Mücadeleye kadar olan dönemde Türk Kara Kuvvetleri. Ankara: Army Printing House and Directorate of Printed Documents.

MSY: 70-1C Recruitment Directive, General Principles, TGS Printing House, No: 2000/145 Ankara, 2000.

Mullins, L. J. (1999). Management and Organizational Behavior. London: Financial Times.

Newstrom, J. W., \& Davis, K. (2002). Human Behavior at Work. Organizational Behavior, p. 272.

Organizational structure, http://dover.idf.il/IDF/English/about/structure, retrieved on 06.12.2010.

ÖGEL, B. (1991). Türk kültür tarihine giriş: Türklerde ordu, ordugâh ve otağ; Devlet, ordu ve aile disiplininin temelleri, Hunlardan Osmanlılara. (D. S. Yilmaz, Ed.) Ankara: Prime Ministry Printing House.

Öztorun, N. (2009). Ulusal Savunma: Strateji, Teknoloji, Savaş. (D. S. Yılmaz, Ed.) Istanbul: Kum Saati Publication Ltd. Co.

Ruscuklu, B. (December 2005). Kore Savaşı: Unutulan savaş ve Gazi Faruk Pekerol'un anıları (p. 246) ALFA Printing Publication Distribution Ltd. Co.

Sayllan, N. D. (1996). Kore Harbinde Türklerle. Ministry of National Education Publications: 2935, Scientific and Cultural Works: 848 (pp. 465 - 466), Istanbul: National Education Printing House.

Russian Armed Forces, http://www.mil.ru/eng/1862/index.shtml, retrieved 03.01.2011

Silva, Mark. War Czar: Consider draft and shorter deployments, 10 August 2007, http://www.swamppolitics.com/politics/blog/2007/08/war_czar_consider_draft_and_s horter_sh.html, retrieved on 11.10.2010

Staff, United States poised to implement mandatory draft?, 05 June 2006, http://www.halifaxalive.com/content/view/755/2/, retrieved on 11.10.2010.

Soldier selection, http://www.armedforces.co.uk/army/listenings/10137.html, retrieved on 22.10.2010. 
Structure and organization of the Chinese Armed Forces,

http://eng.mod.en.cn/ArmedForces/index.htm, retrieved on 02.11.2010.

The military doctrine of the Republic of Armenia,

http://www.mil.am/eng/index.php?page=104, retrieved on 06.09.2007.

The report of the Independent Commission on the Security Forces of Iraq, http://csis.org/files/media/csis/pubs/isf.pdf, retrieved on 24.01.2011.

TRADOC, http://www.tradoc.army.mil/about.htm, retrieved on 22.10.2010.

US Army National Guard, http://www.arng.army.mil/abouts/Pages/default.aspx, retrieved on 13.05.2011.

US Army Organization, http://www.army.mil/info/organization/, retrieved 22.10.2010.

US Army Reserve Command,

http://www.usar.army.mil/ARWEB/ORGANIZATION/COMMANDSTRUCTURE/U SARC/Pages/default.aspx, retrieved on 11.05.2011.

West Point, http://usma.edu/about.asp, retrieved on 22.10.2010 